\title{
THE
}

\section{Racial/ethnic differences in consumer financial capability: The role of financial education}

\author{
Kyoung Tae Kim
}

Jing Jian Xiao

University of Rhode Island, xiao@uri.edu

Follow this and additional works at: https://digitalcommons.uri.edu/hdf_facpubs

The University of Rhode Island Faculty have made this article openly available.

Please let us know how Open Access to this research benefits you.

This is a pre-publication author manuscript of the final, published article.

Terms of Use

This article is made available under the terms and conditions applicable towards Open Access Policy Articles, as set forth in our Terms of Use.

\section{Citation/Publisher Attribution}

Kim, K. T., \& Xiao, J. J. (forthcoming). Racial/ethnic differences in consumer financial capability: The role of financial education. International Journal of Consumer Studies. http://doi.org/10.1111/ijcs.12628

Available at: https://doi.org/10.1111/ijcs.12628

This Article is brought to you for free and open access by the Human Development and Family Science at DigitalCommons@URI. It has been accepted for inclusion in Human Development and Family Science Faculty Publications by an authorized administrator of DigitalCommons@URI. For more information, please contact digitalcommons-group@uri.edu. 
Kim, K. T., \& Xiao, J. J. (forthcoming). Racial/ethnic differences in consumer financial capability: The role of financial education. International Journal of Consumer Studies. http://doi.org/10.1111/ijcs.12628

\title{
Racial/ethnic differences in consumer financial capability:
}

The role of financial education

\author{
Kyoung Tae Kim, Ph.D. \\ Associate Professor \\ Department of Consumer Sciences \\ University of Alabama \\ 316-C Adams Hall, Box 870158 \\ Tuscaloosa, AL 35487, USA \\ Phone: 1.205.348.9167 \\ E-mail: ktkim@ches.ua.edu
}

\author{
Jing Jian Xiao, Ph.D., Corresponding author \\ Professor \\ Department of Human Development and Family Studies \\ University of Rhode Island
}

Transition Center, 2 Lower College Road

Kingston, RI 02881, USA

Phone: 1.401 .874 .2547

E-mail: xiao@uri.edu 
Racial/ethnic differences in financial capability

\title{
Racial/ethnic Differences in Consumer Financial Capability:
}

\section{The Role of Financial Education}

\begin{abstract}
This study examined racial/ethnic differences in financial capability controlling for various factors focusing on the role of financial education. Further, we investigated contributing factors to clarify where such gap stems. Regression results using data from the 2018 US National Financial Capability Study indicated that Whites had a higher level of financial capability across all indicators than other racial/ethnic minority groups. Respondents who participated in the financial education had a higher level of financial capability than those without financial education. Multiple sources, hours and quality of financial education were positively associated with the level of financial capability. Decomposition analyses showed that age, income, negative income shock and banking status contributed to explaining the gaps of financial capability between Black and White respondents as well as between Hispanic and White respondents. Financial education was a contributing factor only to explain the Black-White difference and it may narrow the gap. However, we found substantial unexplained gaps between Black and Hispanic respondents attributed by unobservable characteristics. Results of this study provide important insights into the racial/ethnic disparities in financial capability that have implications for consumer policymakers, educators, and researchers.
\end{abstract}

KEYWORDS: Race; Ethnicity; Financial capability; Financial education; National Financial Capability Study 
Racial/ethnic differences in financial capability

\section{INTRODUCTION}

Theoretically, consumer capability is important for consumers to make optimal financial decisions. In the traditional economic theory, consumers are rational agents, fully informed and able to make optimal decisions in a long term such as described in the life-cycle hypothesis (Modigliani, 1986). However, many consumers are not rational as found in numerous studies in behavioral economics (Thaler, 2016). Increasing financial capability is to help improve decision making skills that has the important economic significance (Lusardi \& Mitchell, 2014). The positive association between financial capability and financial decisions is grounded within the theory of bounded rationality (Simon, 2000). Furthermore, research shows that consumer financial capability may contribute to consumer subjective financial wellbeing (Xiao, Chen, \& Chen, 2014; Xiao \& Porto, 2017).

Financial capability can be defined variously by researchers and the broadest definition is to refer financial capability as knowledge, habits (behavior), status, and access (Lin et al., 2016). Financial capability reflects people's knowledge of financial matters, their ability to manage their money and to take control of their finances (Taylor, 2011). Research on financial capability not only concerns knowledge of consumers, but also the actual behavior of consumers and its prerequisites such as skills and attitudes (Hoelzl \& Kapteyn, 2011). UK played a leadership role in the movement of promoting financial capability by conducting national surveys. The first financial capability survey conducted in UK used financial behavior factors to measure financial capability (Atkinson, McKay, Kempson, \& Collard, 2006). Financial literacy or knowledge plays an important role in forming consumer financial capability (Lusardi \& Mitchell, 2014). UK researchers defined financial capability with three components: knowledge, skills, and attitudes (Kempson, Collard, \& Moore, 2006). Financial capability can also be reflected by the financial asset range (Cui, Xiao \& Yi, 2019). Besides consumer individual abilities, financial capability also refers to consumer access to needed financial services that implies necessary government interventions for supporting disadvantaged consumers (Johnson \& Sherraden, 2007). In this study, we assume that financial knowledge and financial behavior are the important components of financial 
capability and define financial capability as the ability to apply appropriate financial knowledge and perform desirable financial behavior for achieving financial wellbeing (Xiao et al., 2014). Based on this definition, financial knowledge and financial behavior should be positively correlated to help achieve financial wellbeing. Also both objective and subjective measures of the two components (knowledge and behavior) and the overall capability should be positively associated. We choose this definition instead of other definitions that include other components of financial capability such as financial status, skill, attitude, and access for two reasons. First, we attempt to focus on personal ability that excludes status and access variables. Second, skills and attitudes specified by other researchers (e.g. Kempson et al., 2006) are considered in our definition of financial capability. For example, skills refer to two sets of activities, information gathering and record-keeping, and financial planning (saving, spending, and budgeting) (Kempson et al., 2006), which is considered as financial behavior in our definition. Attitudes include willingness to invest time, able to gain access to information, and be confident to exercise skills (Kempson et al., 2006) that are included in the perceived financial capability. We understand that some researchers may believe that financial skill and financial attitude are two distinct concepts that should be treated separately. However, because of the limitation of the dataset, no variables explicitly measure financial skill and financial attitude, we consider this a limitation of this study.

Research on financial literacy or financial capability has been exploded in recent decades. Several factors are examined in explaining financial capability such as gender (Chen \& Volpe, 2002; Fonseca, Mullen, Zamarro, \& Zissimopoulos, 2012), age (Henager \& Cude, 2016; Xiao et al., 2015), and financial education (Wagner \& Walstad, 2019; Xiao \& O’Neill, 2016). Recently, some studies examined financial capability across different countries such as Canada, Italy, the UK, the US (Nicolini, Cude \& Chatterjee, 2013), Poland (Potocki \& Cierpiał-Wolan, 2019), South Africa (Reyers, 2019), Spain (Mancebon et al., 2019), and Malaysia (Hamid \& Loke, 2020). However, the issue of racial/ethnic differences in financial capability has been understudied relatively with an exception that examined White and minority differences in financial literacy (Al-Bahrani, Weathers, \& Patel, 2019). This study is to fill out this gap. 
Racial/ethnic differences in financial capability

The purpose of this study was to examine racial/ethnic differences in financial capability controlling for various factors. Further, we investigated what factors explain the racial/ethnic difference in various measures of financial capability. Extended from previous studies on financial capability, we focused on the role of financial education as well as other contributing factors in explaining financial capability. Additionally, we examined associations of multiple sources, hours, and the quality of financial education with financial capability among those who received financial educations. For empirical analyses, we used data from the 2018 US National Financial Capability Studies (NFCS) commissioned by the FINRA Investor Education Foundation.

This study contributed to the existing literature in twofold. First, this study is one of the first attempts to investigate racial/ethnic disparities in financial capability to clarify where such gaps stemmed. Second, we considered financial education as a salient factor explaining financial capability, which are understudied relatively. Results of this study provide important insights on the racial/ethnic disparities in financial capability that have implications for consumer financial policymakers, educators, and researchers.

\section{LITERATURE REVIEW AND HYPOTHESES}

Kempson et al. (2006) provided an informative review of the evolution of the concept of financial capability. Based on their review, financial capability was first proposed as financial literacy but it was defined as the ability to make informed judgements and take effective decisions regarding the use and management of money (Noctor, Stoney, \& Stradling, 1992). Defining financial literacy as consumer ability was also seen in an earlier literature review (Mason \& Wilson, 2000) and a more recent literature review (Lusardi \& Mitchell, 2014). Since 2006, UK first used financial capability in its national survey (Atkinson et al., 2006), in which financial capability was operationalized as financial behaviors with 
Racial/ethnic differences in financial capability

following domains: (a) managing money, (b) planning ahead, (c) choosing products and (d) staying informed. Since then, researchers conducted financial capability research with various definitions.

Huston (2010) emphasized that financial literacy refers to not only financial knowledge but also application of financial knowledge. Taylor (2011) used a measure of financial capability combining both financial behaviors and outcomes. Researchers also used financial knowledge, behavior, and perceived financial capability to measure financial capability (Xiao et al., 2014; Xiao \& O’Neill, 2016). As stated in the Introduction, previous researchers have examined various contributing factors to one's level of financial capability such as age (Henager \& Cude, 2016; Xiao, Chen \& Sun, 2015), gender (Chen \& Volpe, 2002; Fonseca et al., 2012), and financial education (Wagner \& Walstad, 2019; Xiao \& O’Neill, 2016).

Based on our definition of financial capability, when financial capability is disaggregated into two components, financial literacy and financial behavior, several empirical studies are found to analyze racial/ethnic differences in each aspect. Lusardi and Mitchell (2014) presented a comprehensive review of financial literacy among various groups and mentioned noticeable differences across race/ethnicity groups. In addition, Al-Bahrani, Weathers, and Patel (2019) found that minority groups had a lower level of financial knowledge than Whites, but they did not analyze specific racial/ethnic group comparisons (e.g., White vs. African Americans).

With respect to financial behaviors, some recent studies examined associated factors with shortterm and long-term financial behaviors (Henager \& Cude, 2016; Kim, Seay \& Anderson, 2019; Wagner \& Walstad, 2019) using the NFCS dataset. Henager and Cude (2016), and Wagner and Walstad (2019) provided evidence about racial/ethnic gaps in financial behaviors with Whites displaying more desirable financial behaviors than the minority, but they used one combined "minority" category for diverse minority groups. Kim et al. (2019) is one of the first NFCS research to examine racial/ethnic differences in financial behavior. They found that Blacks were less likely while Hispanics more likely than Whites to perform short-term financial behaviors. 
Racial/ethnic differences in financial capability

Researchers developed various conceptual frameworks to understand consumer financial capability from a life course perspective (Leskinen \& Raijas, 2006), a behavioral perspective (Kempson et al., 2006), or a legal perspective (Nicolini, 2006). In this study, we used the health development theory and capability theory to conceptualize the development of financial capability. The reasons for using these theories are two: the theories are relevant to the topic of this study and the theories are well known and widely cited in the field of economics and other social science fields. Based on the health development theory (Grossman, 1972), a person's health is developed based on the initial stock and later investment. We assume that a person's capability is positively associated with one's health and then the determinants of the capability should be the same, the initial stock and later investment. Based on the capability theory (Sen, 1993/2008), a person's capability should not be only determined by a person's internal ability but also environments that allow the realization of the ability. Based on this theory, some scholars included financial service access to the definition of financial capability (Johnson \& Sherredan, 2007).

In this study, we focus on individual ability and consider environment factors as external forces such as discriminations. Based on the above conceptual discussion, a person's financial ability is affected by initial stock, later investment, and environmental factors. Initial stock can be reflected by many consumer background characteristics that include demographic and resource related factors. Later investments refer to financial education received to accumulate financial knowledge. Environmental factors can be many but in this study, we focus on potential discrimination, following previous research on the wealth gap (e.g., Kakar, Daniels, \& Petrovska, 2019). The literature of financial knowledge and behavior shows that compared to Whites, minority groups demonstrated lower financial knowledge and fewer desirable financial behaviors, which may be caused by the above factors. Then, we propose following hypotheses:

H1: Given consumer background and financial education factors, Whites score higher in financial capability indicators than Blacks. 
Racial/ethnic differences in financial capability

H2: Given consumer background and financial education factors, Whites score higher in financial capability indicators than Hispanics.

In the literature of financial capability, researchers used decomposition analyses to examine critical factors explaining the financial literacy gap between White and minority groups. Among consumer characteristics that are used to explain the gap, two sets of factors may be critical, resource and knowledge. Previous research found resource factors may be more important than knowledge factors to explain the gap (Al-Bahrani et al., 2019). In this study, we propose the following hypotheses:

H3: Resource factors contribute more than knowledge factors to explain the Black-White gap in financial capability.

H4: Resource factors contribute more than knowledge factors to explain the Hispanic-White gap in financial capability.

\section{METHODS}

\subsection{Dataset and Sample Selection}

We used the 2018 US National Financial Capability Studies (NFCS) dataset managed and released by the FINRA Investor Education Foundation. The 2018 state-by-state survey contains information collected between June and October 2018, from roughly 500 respondents per state and District of Columbia with oversamples for Oregon and Washington. For this study, we dropped respondents who answered "prefer not to say" or "do not know" to our dependent and independent variables. With respect to objective financial knowledge questions, we excluded cases where the respondents chose "prefer not to say". The total sample of the 2018 NFCS is 27,091 , but the final analytic sample included 19,449 respondents. Compared to previous NFCS waves, the 2018 survey included new variables such as several financial education variables that were used in this study. 


\subsection{Dependent variable: Financial capability}

The dependent variables were four indicators of financial capability and one index variable following previous studies on financial capabilities (Xiao \& O’Neill, 2016; Xiao \& Porto, 2017). The four indicators include (a) objective financial knowledge (0-6), (b) subjective financial knowledge (1-7), (c) perceived financial capability (1-7) and (d) desired financial behavior (0-6) (short-term 0-3 \& long-term 0-3). Firstly, the objective knowledge variable was created based on the sum of correct answers to the six financial literacy questions, ranging from 0 to 6 . Six financial knowledge questions were about topics of compounding, inflation, mortgage, bond, stock, and time value of money. Secondly, subjective financial knowledge was measured with the following question: "On a scale from 1 to 7 , where 1 means very low and 7 means very high, how would you assess your overall financial knowledge?"

Thirdly, the perceived financial capability variable was a self-assessment of money management ability with a 7-point scale asked in the following question, "How strongly do you agree or disagree with the following statements? - I am good at dealing with day-to-day financial matters, such as checking accounts, credit and debit cards, and tracking expenses." Fourthly, desirable financial behavior was composed of three short-term and three long-term behaviors (e.g., Kim et al., 2019). The short-term financial behaviors include saving for emergency, underspending and not overdrawing a checking account while the long-term financial behaviors include planning the amount necessary for retirement, owning retirement plans, and owning investments outside of retirement accounts. Each answer was coded as a binary variable and responses were summed to construct one index that ranged from 0 to 6 . Lastly, following the approach of Xiao et al. (2015) and Xiao and O’Neill (2016), the composite financial capability index was estimated by summing $\mathrm{Z}$ scores of four financial capability measures ranged from 10.46 to 5.24 . 


\subsection{Key independent variable}

\subsubsection{Race/ethnicity}

Race/ethnicity is the main variable of interest. In the public version of NFCS dataset, race/ethnicity of respondents is categorized into two groups: White and non-White. This study used the restricted version of NFCS dataset which includes five groups of race/ethnicity; White non-Hispanic, Black non-Hispanic, Hispanic, Asian non-Hispanic, and other non-Hispanic. However, due to small sample size of the last two groups, this study focused on the three major racial/ethnic groups and for convenience we call them Whites, Blacks and Hispanics, respectively.

\subsubsection{Financial Education}

A binary indicator of financial education was created whether or not the respondent had participated in financial education offered by an educational institution or a workplace. The 2018 NFCS also collects another question to ask where a respondent received the financial education such as high school, college, and workplace. We created mutually exclusive categories of financial education sources as follows; (1) no financial education, (2) high school only; (3) college only; (4) employer only; (5) high school and college; (6) high school and employer; (7) college and employer; and (8) high school, college, and employer. Further, two additional questions that are new in the 2018 NFCS dataset, (a) the number of hours of financial education received (1-2 hours, 3-10 hours, and more than 10 hours), and (b) subjective rating of the financial education quality from the respondents who had participated in financial education (ranged 1 to 7).

3.4 Control variables 
Racial/ethnic differences in financial capability

Following previous studies on financial capability, this study included a set of control variables such as age, gender (male/female), marital status (married, single, separated/divorce/widow), education (less than high school, high school diploma, some college, associate degree, bachelor degree, post-bachelor degree), having a dependent child (yes/no), employment status (full-time worker, self-employed, part-time worker, homemaker, student, disabled, unemployed, retired), income, substantial income drop (yes/no) and banking status (yes/no). Lastly, we also controlled for region, using the state of residence variable, to account for the variation in financial capability due to the unobserved regional sentiments towards various financial behaviors and differences in state-level policies. We used the states with the highest values of each financial capability measure as reference states. For example, South Dakota and Mississippi were reference states for objective and subjective financial knowledge, respectively.

\subsection{Empirical specification}

\subsubsection{Ordinary least squares (OLS) regression model}

Firstly, we conducted OLS regression analyses on five dependent variables; objective financial knowledge, subjective financial knowledge, desired financial behavior, perceived financial capability, and the financial capability index. In the estimated OLS regression model, the White group is used as a reference group for racial/ethnicity. $X_{i}$ denotes vector of control variables.

$$
\text { Financial Capability }_{i}=\beta_{0}+\beta_{1} \text { Black }_{i}+\beta_{2} \text { Hispanic }_{i}+\gamma X_{i} \ldots \ldots \text { (1) }
$$

\subsubsection{Decomposition analysis}

In addition to regression analyses, we conducted decomposition analyses (Blinder, 1973; Oaxaca, 1973) to examine what factors explain the differences in financial capability variables between race/ethnic groups. Equation (2) illustrates how to decompose the mean differences in various financial capability measures between racial/ethnic groups. 


$$
\bar{Y}^{A}-\bar{Y}^{B}=\left[\left(\bar{X}^{A}-\bar{X}^{B}\right) \widehat{\beta}^{A}\right]+\left[\bar{X}^{B}\left(\widehat{\beta}^{A}-\widehat{\beta}^{B}\right)\right]
$$

$\bar{Y}^{A}$ and $\bar{Y}^{B}$ indicate the averages of dependent variables for race/ethnicity group A and B. $\bar{X}$ is the row vector of mean value for independent variables and $\widehat{\beta}$ denotes the vector of coefficients estimated for each group. Decomposing the average difference in dependent variable in such setting allows us to examine the relative contribution of each of the considered factors. On the right hand of the equation, first term represents the impact of between-group differences in the explanatory variables $X$, evaluated using the coefficients for group $A$. The second term is the differential not explained by these differences in observed characteristics $X$. If $X$ perfectly represents determinants of the gap, the second term should indicate the impact of environment such as discrimination. Here, we assume $X$ captures major determinants of the gap, then we will interpret the second part, or unexplained differences caused by discriminations or other environment factors.

\section{RESULTS}

\subsection{Descriptive results}

Table 1 shows descriptive statistics of five financial capability variables. The mean scores of objective financial knowledge, subjective financial knowledge, perceived financial capability and desired behavior were 3.26, 5.19, 5.84 and 3.55, respectively. We also conducted T-tests to compare two pair-wise comparisons between racial/ethnic groups in each financial capability variable and White was used as the reference group. Whites had significantly higher scores in all financial capability indicators than the two minority groups. Other sample characteristics of pooled and each racial/ethnic group are presented in Appendix 1.

[Insert Table 1] 
4.2 Multivariate results: OLS regressions

Results from five Ordinary Least Squares regressions are shown in Table 2. Whites' score tended to be higher in several financial capability indicators than minority groups even after controlling for various factors. In particular, Whites' score tend to be higher in objective financial knowledge, desired financial behavior, and the financial capability index than Blacks and Hispanics. Blacks had higher subjective financial knowledge while Hispanic had lower perceived financial capability than Whites. These results are mostly consistent with $\mathrm{H} 1$ and $\mathrm{H} 2$ except for one (Blacks scored better than Whites in subjective financial knowledge).

With respect to financial education, respondents who participated in the financial education had a higher level of financial capability than those without financial education and the results were held consistently across five measures. Age is positively related to the level of financial capability. Male respondents had higher financial capability than females. Respondents living with dependent children had lower financial capability while had higher subjective financial knowledge than those without any dependent child. As an educational level increased, the level of financial capability increased steadily. Employment status had some mixed pattern, but full-time working respondents had higher financial capability than most counterparts except for self-employed and retired. Household income was positively associated with the level of financial capability. Respondents who experienced a substantial income drop had lower financial capability while banked respondents had higher financial capability than their counterparts.

[Insert Table 2]

4.3 Additional analyses: Various sources, invested time and quality of financial education 
Racial/ethnic differences in financial capability

In order to take advantage of the new information from 2018 NFCS and explore associations between a set of financial education characteristics and financial capability, we conducted additional regression analyses. As shown in Table 3, respondents who had participated in multiple sources of financial education were more likely to have higher levels of financial capability than those without receiving financial education across five indicators. The association patterns between racial/ethnic groups and financial capability variables are the same as we reported in Table 2.

Among the subsample of respondents who received financial education, we found mixed results of racial/ethnic differences in financial capability (see Table 4). White respondents had more objective knowledge than Black and Hispanic respondents while there was no difference in subjective financial knowledge. In addition, Black respondents scored higher while Hispanic respondents scored lower in perceived financial capability than Whites. White respondents scored higher in the financial capability index than Hispanic respondents. With respect to two additional financial education variables, respondents who received more than 10 hours of financial education scored higher in all financial capability indicators except for the subjective financial knowledge and perceived financial capability. Receiving 3-10 hours was positively associated with objective financial knowledge and desired financial behaviors. The overall quality of financial education was positively associated with all financial capability variables except for the objective financial knowledge.

[Insert Tables 3 and 4]

\subsection{Decomposition analyses: Blacks vs. Whites}

Results from the decomposition analyses across three pairwise comparisons are presented in Table 5, Table 6 and Table 7. In the following, we will first discuss the total difference and the rate of explained difference to explain the model fit of decomposition analyses. Then, we will discuss four to five important 
Racial/ethnic differences in financial capability

contributing factors with high percentages of explained differences and their values for explaining the racial/ethnic gap in financial capability.

Table 5 presents results from the decomposition analyses for the Black-White differences across five measures of financial capability. The difference of subjective financial knowledge in specification (2) was not found to be significant, so the rate of explained difference was not discussed. The estimated total difference in the level of financial capability was ranged from -0.9674 to -0.2682 and the percentage of explained difference between Black and White respondents was ranged from $40.5 \%$ to $123.7 \%$. Age, income, banking status, unexpected income drop and financial education contributed to differences in financial capability between Black and White respondents across five measures. Factors with positive (negative) values of explained percentages contributed to widen (narrow) the ethnic/racial gap in each financial capability indicator. Age and income are two most important factors accounted for $25.2 \%-44.8 \%$ and $25.5 \%-43.0 \%$, respectively. The mean age of Black respondents was significantly lower than White respondents as shown in Appendix. The lower age of Blacks increased the difference in objective financial knowledge between Black and White by $44.8 \%$ (See specification (1) in Table 5).

Financial education was the only important contributor with negative value of percentage explained, suggesting it may narrow the gap in financial capability between Black and White respondents. Given that Black respondents had a higher percentage of receiving financial education than White (see Appendix), if they had the same level of financial education as White respondents, they would have a lower level of financial capability. As shown in specification (1) in Table 5, the higher \% of financial education recipients of Black respondents decreased the difference in objective financial knowledge between Black and White by $7.4 \%$. Since the explaining power of financial education is much lower than that of income, $\mathrm{H} 3$ is supported.

[Insert Table 5] 
Racial/ethnic differences in financial capability

\subsection{Decomposition analyses: Hispanics vs. Whites}

Table 6 presents results from the decomposition analyses for the Hispanic-White differences across five financial capability measures. The estimated total difference in the level of financial capability was ranged from -0.6352 to -0.2247 and the percentage of explained difference between Hispanic and White respondents was ranged from $62.7 \%$ to $111.9 \%$. Similar to the results in Table 5, age, income, banking status and unexpected income drop were important contributors to the difference in financial capability between Hispanic and White respondent across five different measures. In addition, we found that having a dependent child and gender (mainly for financial knowledge measures) could explain the racial/ethnic difference. Those major contributing factors had positive values of percentages explained indicating that characteristics contributed to widen the Hispanic-White gap in each financial capability indicator. Hispanic group had right-skewed distribution than White group (see Appendix). The lower level of income in Hispanics increased the difference in objective financial knowledge between Hispanic and White by $18.6 \%$ (See specification (1) in Table 6). Lastly, financial education was not a significant factor to explain the Hispanic-White gap in financial capability. The results are consistent with H4.

\section{[Insert Table 6]}

\subsection{Decomposition analyses: Blacks vs. Hispanics}

In addition to the two main pair-wise comparisons, we conducted the following decomposition analyses for the Black-Hispanic differences across five financial capability measures as shown in Table 7. The estimated total differences in the level of financial capability ranged from -0.3322 to 0.2003 and the explained differences between Black and Hispanic respondents ranged from -0.1099 to 0.0033. Given the little differences explained by observable variables, our decomposition results were not found to be meaningful except for the results of desirable financial behaviors. Income, banking status, financial education and gender were important contributors to the difference in desired financial behaviors between Black and Hispanic respondents. In particular, income and banking status had positive values of 
Racial/ethnic differences in financial capability

percentages explained indicating that characteristics contributed to widen the Black and Hispanic gap while financial education and age had negative percentages explained, suggesting they may narrow the gap. However, we found substantial unexplained gaps in other financial capability variables attributed by unobservable characteristics.

\section{[Insert Table 7]}

\subsection{Robustness check}

This study conducted additional analyses to check the robustness of the results. First, we used a big 3 financial knowledge questions (i.e., compounding, inflation and stock) originally developed by Lusardi and Mitchell (Lusardi \& Mitchell, 2014) as an alternative measure of objective financial knowledge, and we re-defined two related measures of financial capability. Further, we conducted similar analyses with the consideration of “don't know" response. For example, “don't know” responses of subjective knowledge and perceived financial capability were coded as the lowest value. Additional robustness checks supported our primary findings. Full results of robustness checks are available from the authors upon request.

\section{DISCUSSION AND IMPLICATIONS}

Findings of this study have implications for consumer policy makers. Policy makers should be aware of gaps in financial capability between Whites and racially/ethnically minority groups. When they make economic policies, they should consider the needs of communities with large minority populations. In addition, they should be aware that major contributors to cause the gap are economic factors such as income, banking status and negative income shock. To narrow the gap, policy makers should develop policies to help raise employment opportunities and improve business environments especially in 
Racial/ethnic differences in financial capability

communities with large racial/ethnical minority populations. They may also develop policies to help older people to maintain jobs and increase minimum wages.

One of notable findings is the important role of financial education on financial capability. We found that respondents who participated in financial education had higher financial capability than those not experiencing financial education, which is consistent with previous research (Xiao \& O'Neill, 2016). We newly found that the number of hours and quality of financial education were positively associated with financial capability. Further, financial education was the only contributing factor to reduce the Black-White differences in financial capability. Extended from the existing financial education mandate programs by the US federal and state governments (Council for Economic Education, 2018), they should provide in-depth and intensive education to them to help close the gap and also provide resources to encourage communities to offer tailored financial education programs especially to those who are Blacks and Hispanics.

Results of this study also have implications for consumer educators. Educators should be aware of racial/ethnic differences in financial capability among various racial/ethnic groups. When they design education programs, they should take race and ethnicity into accounts. Different racial/ethnic populations may have their own cultures and habits in learning and financial challenges faced by them may be also different, which should be used for designing effective education programs (Anong, 2016; Porto, 2016; Yao, 2016). Results also indicate possible contributing factors for the gap of financial capability between Whites and racial/ethnic minority groups and these factors should be considered when education programs are designed and implemented to communities with large minority populations. Results show that economic factors such as income level, unexpected income drop and banking status are factors contributing to the gaps between Whites and Blacks and between White and Hispanics. Compared to the financial education factor, the resource related factors seem more salient to explain the gap. Educators may need to consider these findings when they design financial education programs and meet diverse educational needs of consumers, especially those with limited resources. When educators working with 
Racial/ethnic differences in financial capability

these minority clients, they should offer information to help them improve financial status with an appropriate cash flow management.

This study contributes to the existing literature in three ways. First, we extended previous research to examine racial/ethnic differences in financial capability with more specific racial/ethnic groups and a broader definition of financial capability. Previous research examined the White-minority group difference in financial literacy (e.g., Al-Bahrani et al., 2019). Our study conducted analyses between White and two specific minority groups, Black-White, and Hispanic-White. Also, our study examined not only financial literacy (knowledge) but also financial behavior and financial capability. Second, our study extended previous research by examining potential effects of two new financial education variables on financial capability. In previous research, participation and sources of financial education were examined (Xiao \& O’Neill, 2016; Xiao \& Porto, 2017). In this study, taking advantage of new information from the 2018 NFCS, we also examined potential effects of education hours and perceived quality on financial capability, which generated helpful information for financial education program design and delivery. Third, previous research on racial/ethical differences in financial literacy did not use an explicit conceptual framework. In this study, we did not develop a perfect theory but tried to apply two established theories (Grossman, 1972; Sen, 1993/2008) and proposed a conceptual framework to guide hypothesis development.

Limitations of the study and future directions are discussed following the general approach used in previous research (Kumar \& Paul, 2018; Kumar, Paul, \& Unnithan, 2019). This study has several limitations to be noted. First, this study did not address any causal inferences about the relation between race/ethnicity and financial capability given the cross-sectional nature of the NFCS dataset. Future research using a longitudinal dataset could allow researchers to account for the causal inference. Second, this study confirmed that there are significant racial/ethnic disparities in financial capability with some important contributing factors, but there are still unexplained gaps attributed by unobservable 
Racial/ethnic differences in financial capability

characteristics, e.g., financial experience or social exclusion among minority groups discussed by Birkenmaier and $\mathrm{Fu}$ (2018). Future research is needed to further clarify this issue.

Third, this study started to propose a conceptual framework for determinants of financial capability. However, it is far from adequate for forming a matured theory. Future research on racial/ethnic differences in financial capability may further develop the conceptual framework started from this study to better explain this important social phenomenon. Fourth, the dataset used in this study does not have information about locations of respondents' high school and college financial education that may result in measurement errors when self-reported financial education sources are used. In future research, data about more comprehensive financial education sources should be used to address this limitation. In spite of these limitations, results from this study provide a foundation for future research on consumer financial capability. Fifth, this study did not explicitly measure financial skill and financial attitude due to the limitation of the dataset. Future research may further conceptually clarify the differences between financial behavior, skill, and attitude and use datasets with these variables measured explicitly.

\section{CONCLUSION}

Using the 2018 US National Financial Capability Study dataset, this study investigated racial/ethnic disparities in financial capability. Regression results indicated that Whites had a higher level of financial capability than other racial/ethnic minority groups after controlling for socioeconomic factors. Further, financial education was positively associated with the level of financial capability. Extended from the existing literature on financial capability, this study examined contributing factors to clarify where such gap stems using the Blinder-Oaxaca decomposition technique. Age, income, banking status and unexpected income drop were important contributors to explain the gap between Black and White respondent as well as between Hispanic and White respondents across five different measures. Financial education contributed to narrow the gap of in financial capability between Blacks and Whites.

\section{Reference}

Al-Bahrani, A., Weathers, J., \& Patel, D. (2019). Racial differences in the returns to financial literacy education. Journal of Consumer Affairs, 53(2), 572-599. 
Anong, S. (2016). Financial wellbeing of African Americans. In J. J. Xiao (ed.). Handbook of consumer finance research (pp. 215-224). New York: Springer.

Atkinson, A., McKay, S., Kempson, E., \& Collard, S. (2006). Levels of financial capability in the UK: Results of a baseline survey. Consumer Research Report 47. London: Financial Services Authority.

Birkenmaier, J., \& Fu, Q. (2018). Household financial access and use of alternative financial services in the US: Two sides of the same coin? Social Indicators Research, 139(3), 1169-1185.

Blinder, A. (1973). Wage discrimination: Reduced form and structural estimates. Journal of Human Resources, 8(4), 436-455.

Chen, H., \& Volpe, R. P. (2002). Gender differences in personal financial literacy among college students. Financial services review, 11(3), 289-307.

Council for Economic Education. (2018). Survey of the states: Economic and personal finance education in our nation's schools. New York: Council for Economic Education.

Cui, X., Xiao, J. J., \& Yi, J. (2019). Employment type, residential status and consumer financial capability: Evidence from China Household Finance Survey. The Singapore Economic Review, 64(01), 57-81.

Fonseca, R., Mullen, K. J., Zamarro, G., \& Zissimopoulos, J. (2012). What explains the gender gap in financial literacy? The role of household decision making. Journal of Consumer Affairs, 46(1), 90-106.

Grossman, M. (1972). On the concept of health capital and the demand for health. Journal of Political Economy, 80(2), 223-255.

Hamid, F. S., \& Loke, Y. J. (2020). Financial literacy, money management skill and credit card repayments. International Journal of Consumer Studies. DOI: 10.1111/ijcs.12614

Henager, R., \& Cude, B. J. (2016). Financial literacy and long-and short-term financial behavior in different age groups. Journal of Financial Counseling and Planning, 27(1), 3-19.

Hoelzl, E., \& Kapteyn, A. (2011). Financial capability. Journal of Economic Psychology, 32 (4), 543545.

Huston, S. J. (2010). Measuring financial literacy. Journal of Consumer Affairs, 44(2), 296-316.

Johnson, E., \& Sherraden, M. S. (2007). From financial literacy to financial capability among youth. Journal of Sociology \& Social Welfare, 34 (3), 119-146.

Kakar, V., Daniels Jr, G. E., \& Petrovska, O. (2019). Does student loan debt contribute to racial wealth gaps? A decomposition analysis. Journal of Consumer Affairs, 53(4), 1920-1947. 
Kempson, E., Collard, S., \& Moore, N. (2006). Measuring financial capability: An exploratory study for the Financial Services Authority. In Consumer financial capability: Empowering European consumers (pp. 39-76). Brussels: European Credit Research Institute.

Kim, K. T., Somer, A. \& Seay, M. (2019). Financial knowledge and short-term and long-term financial behaviors of Millennials in the United States. Journal of Family and Economic Issues, 40(2), 194-208.

Kumar, A., \& Paul, J. (2018). Mass prestige value and competition between American versus Asian laptop brands in an emerging market-Theory and evidence. International Business Review, 27(5), 969-981.

Kumar, A., Paul, J., \& Unnithan, A. B. (2019). 'Masstige'marketing: A review, synthesis and research agenda. Journal of Business Research, 113, 384-398.

Leskinen, J., \& Raijas, A. (2006). Consumer financial capability-a life cycle approach. In Consumer financial capability: Empowering European consumers (pp. 8-23). Brussels: European Credit Research Institute.

Lin, J. T., Bumcrot, C., Ulicny, T., Lusardi, A., Mottola, G., Kieffer, C., \& Walsh, G. (2016). Financial capability in the United States 2016. Washington, DC: FINRA Investor Education Foundation.

Lusardi, A., \& Mitchell, O. S. (2014). The economic importance of financial literacy: Theory and evidence. Journal of economic literature, 52(1), 5-44.

Mancebon, M., Ximenez-de-Embun, D.P., Mediavilla, M. \& Gomez-Sancho J. (2019), Factors that influence the financial literacy of Spanish consumers. International Journal of Consumer Studies, 43(2), 227-235.

Mason, C. L. J., \& Wilson, R. M. S. (2000). Conceptualising financial literacy. Occasional Paper, 7. Loughborough University.

Modigliani, F. (1986). Life cycle, individual thrift, and the wealth of nations. Science, 234(4777), 704712.

Nicolini, G. (2006). A regulatory perspective on consumer financial capability. Consumer Financial Capability: Empowering European Consumers, (pp. 78-91). Brussels: European Credit Research Institute.

Nicolini, G., Cude, B. \& Chatterjee, S. (2013). Financial literacy: A comparative study across four countries, International Journal of Consumer Studies, 37(6), 689-705.

Noctor, M., Stoney, S., \& Stradling, R. (1992). Financial literacy: a discussion of concepts and competences of financial literacy and opportunities for its introduction into young people's learning. National Foundation for Educational Research. 
Oaxaca, Ronald. (1973). Male-Female Wage Differentials in Urban Labor Markets. International Economic Review, 14(3), 693-709.

Porto, N. (2016). Financial issues of Hispanic Americans. In J. J. Xiao (ed.). Handbook of consumer finance research (pp. 205-214). New York: Springer.

Potocki, T. \& Cierpiał-Wolan, M. (2019). Factors shaping the financial capability of low-income consumers from rural regions of Poland. International Journal of Consumer Studies, 43(2), $187-$ 198.

Reyers, M. (2019). Financial capability and emergency savings among South Africans living above and below the poverty line. International Journal of Consumer Studies, 43(4), 335-347.

Sen, A. (1993/2008). Capability and well-being. In D. M. Hausman (ed.) The philosophy of economics: An anthology, (3 ${ }^{\text {rd }}$ ed.) (pp. 270-293). Cambridge: Cambridge University Press.

Simon, H. A. (2000). Bounded rationality in social science: Today and tomorrow. Mind \& Society, 1(1), 25-39.

Taylor, M. (2011). Measuring financial capability and its determinants using survey data. Social Indicators Research, 102, 297-314.

Thaler, R. H. (2016). Behavioral economics: Past, present, and future. American Economic Review, 106(7), 1577-1600.

Wagner, J., \& Walstad, W. B. (2019). The effects of financial education on short-term and long-term financial behaviors. Journal of Consumer Affairs, 53(1), 234-259.

Xiao, J. J., Chen, C., \& Chen, F. (2014). Consumer financial capability and financial satisfaction. Social indicators research, 118(1), 415-432.

Xiao, J. J., Chen, C., \& Sun, L. (2015). Age differences in consumer financial capability. International Journal of Consumer Studies, 39(4), 387-395.

Xiao, J.J. \& O’Neill, B. (2016). Financial education and financial capability, International Journal of Consumer Studies, 40(6), 712-721.

Xiao, J.J. \& Porto, N. (2017). Financial education and financial satisfaction: Financial literacy, behavior, and capability as mediators. International Journal of Bank Marketing, 35(5), 818-841.

Yao, R. (2016). Financial wellbeing of Asian Americans. In J. J. Xiao (ed.). Handbook of consumer finance research (pp. 225-238). New York: Springer. 
Racial/ethnic differences in financial capability

Table 1. Racial/ethnic disparities in various measures of financial capability, 2018 NFCS

\begin{tabular}{|c|c|c|c|c|c|}
\hline & $\begin{array}{l}\text { (1) Objective financial } \\
\text { knowledge }(0-6)\end{array}$ & $\begin{array}{l}\text { (2) Subjective financial } \\
\text { knowledge (1-7) }\end{array}$ & $\begin{array}{l}\text { (3) Perceived financial } \\
\text { capability (1-7) }\end{array}$ & $\begin{array}{l}\text { (4) Desirable financial } \\
\text { behaviors }(0-6)\end{array}$ & $\begin{array}{l}\text { (5) Financial capability } \\
\text { index }\end{array}$ \\
\hline Mean (median) & $3.2610(3.00)$ & $5.1913(5.00)$ & $5.8379(6.00)$ & $3.5520(4.00)$ & $0(0.2923)$ \\
\hline Standard deviation & 1.6294 & 1.3312 & 1.5490 & 1.7197 & 2.9162 \\
\hline
\end{tabular}

\begin{tabular}{|c|c|c|c|c|c|c|c|c|c|c|}
\hline Race/ethnicity & Mean & Difference & Mean & Difference & Mean & Difference & Mean & Difference & Mean & Difference \\
\hline Black & 2.4520 & $-0.9674^{* * *}$ & 5.1903 & $-0.0245^{* * *}$ & 5.6323 & $-0.2682^{* * *}$ & 2.9674 & $-0.7123^{* * *}$ & -0.9752 & $-1.2063^{* * *}$ \\
\hline Hispanic & 2.7842 & $-0.6352^{* * *}$ & 4.9901 & $-0.2047^{* * *}$ & 5.5239 & $-0.3766^{* * *}$ & 3.0941 & $-0.5855^{* * *}$ & -0.9207 & $-1.1518^{* * *}$ \\
\hline White & 3.4194 & reference & 5.2148 & reference & 5.9005 & reference & 3.6796 & reference & 0.2311 & reference \\
\hline
\end{tabular}

Unweighted results. T-tests were conducted for two pair-wise comparisons in each financial capability variable. Significance level: ${ }^{*} p<.1,{ }^{* * *} p<.05,{ }^{* * *} p<.01$. 
Racial/ethnic differences in financial capability

Table 2. Ordinary least squares regressions on financial capability, 2018 NFCS

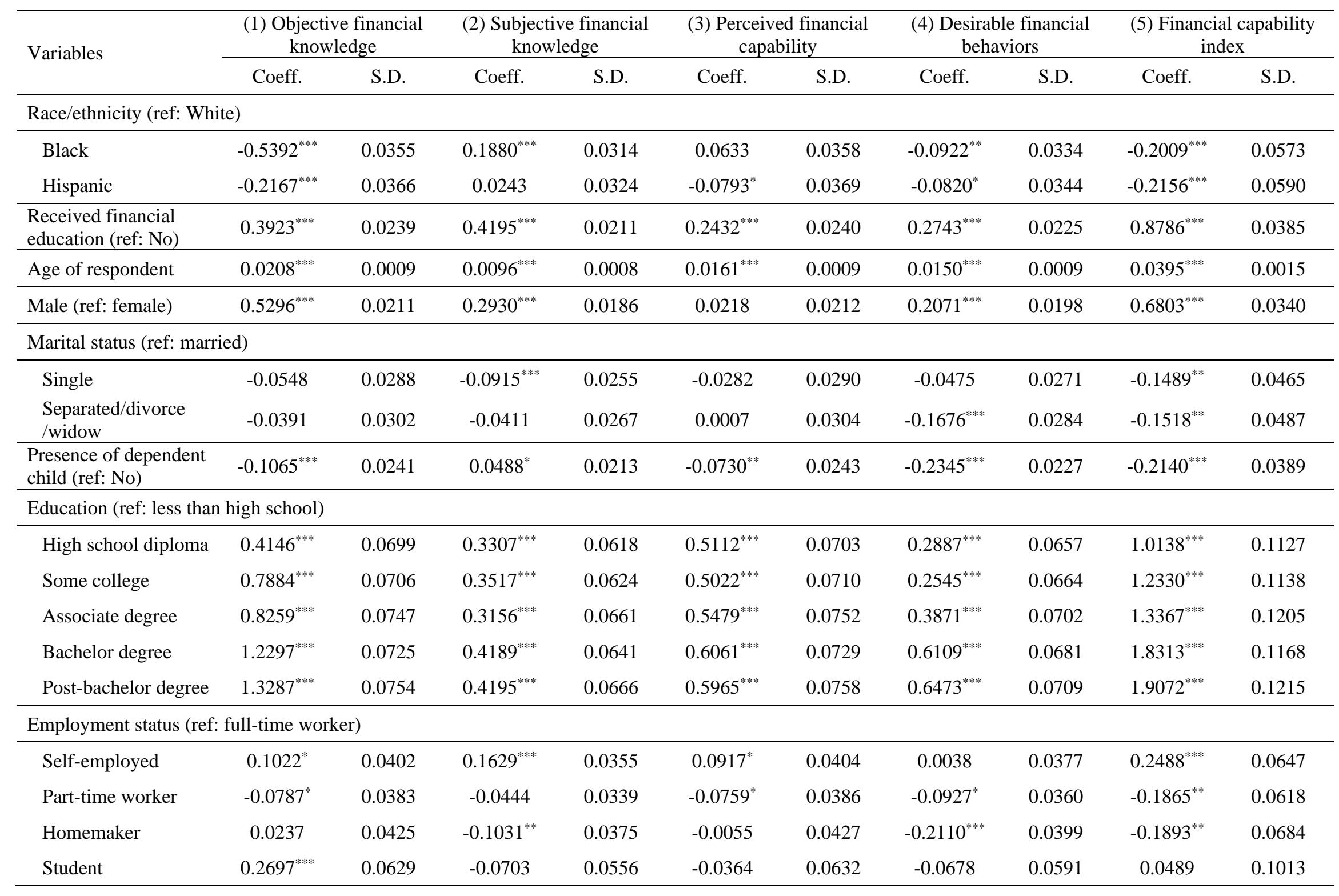




\begin{tabular}{|c|c|c|c|c|c|c|c|c|c|c|}
\hline \multirow{2}{*}{ Variables } & \multicolumn{2}{|c|}{$\begin{array}{l}\text { (1) Objective financial } \\
\text { knowledge }\end{array}$} & \multicolumn{2}{|c|}{$\begin{array}{l}\text { (2) Subjective financial } \\
\text { knowledge }\end{array}$} & \multicolumn{2}{|c|}{$\begin{array}{l}\text { (3) Perceived financial } \\
\text { capability }\end{array}$} & \multicolumn{2}{|c|}{$\begin{array}{c}\text { (4) Desirable financial } \\
\text { behaviors }\end{array}$} & \multicolumn{2}{|c|}{$\begin{array}{l}\text { (5) Financial capability } \\
\text { index }\end{array}$} \\
\hline & Coeff. & S.D. & Coeff. & S.D. & Coeff. & S.D. & Coeff. & S.D. & Coeff. & S.D. \\
\hline Disabled & $-0.1259^{*}$ & 0.0504 & $-0.2009^{* * * *}$ & 0.0445 & $-0.1856^{* * *}$ & 0.0507 & $-0.7426^{* * *}$ & 0.0473 & $-0.7845^{* * *}$ & 0.0812 \\
\hline Unemployed & -0.0271 & 0.0539 & $-0.3095^{* * *}$ & 0.0476 & $-0.2192^{* * *}$ & 0.0542 & $-0.3577^{* * *}$ & 0.0507 & $-0.6043^{* * *}$ & 0.0869 \\
\hline Retired & 0.0386 & 0.0343 & $0.1960^{* * *}$ & 0.0303 & $0.1067^{* *}$ & 0.0345 & $0.2532^{* * *}$ & 0.0322 & $0.3898^{* * *}$ & 0.0553 \\
\hline \multicolumn{11}{|c|}{ Income (ref: less than $\$ 15,000$ ) } \\
\hline$\$ 15,000-\$ 24,999$ & $0.0889^{*}$ & 0.0449 & $0.1626^{* * *}$ & 0.0397 & $0.1104^{*}$ & 0.0452 & $0.1202^{* *}$ & 0.0422 & $0.3207^{* * *}$ & 0.0724 \\
\hline$\$ 25,000-\$ 34,999$ & $0.1489^{* *}$ & 0.0457 & $0.2765^{* * * *}$ & 0.0404 & $0.1786^{* * *}$ & 0.0460 & $0.4316^{* * *}$ & 0.0430 & $0.6700^{* * * *}$ & 0.0737 \\
\hline$\$ 35,000-\$ 49,999$ & $0.3072^{* * * *}$ & 0.0442 & $0.3568^{* * * *}$ & 0.0391 & $0.3038^{* * *}$ & 0.0444 & $0.8228^{* * * *}$ & 0.0415 & $1.1389^{* * *}$ & 0.0712 \\
\hline$\$ 50,000-\$ 74,999$ & $0.4559^{* * *}$ & 0.0441 & $0.4714^{* * *}$ & 0.0390 & $0.3504^{* * *}$ & 0.0443 & $1.1847^{* * *}$ & 0.0414 & $1.5579^{* * *}$ & 0.0710 \\
\hline$\$ 75,000-\$ 99,999$ & $0.4332^{* * *}$ & 0.0475 & $0.6985^{* * *}$ & 0.0420 & $0.5283^{* * *}$ & 0.0478 & $1.5274^{* * *}$ & 0.0446 & $2.0333^{* * *}$ & 0.0765 \\
\hline$\$ 100,000-\$ 149,999$ & $0.7010^{* * * *}$ & 0.0500 & $0.6841^{* * * *}$ & 0.0442 & $0.5653^{* * * *}$ & 0.0503 & $1.7161^{* * * *}$ & 0.0470 & $2.3213^{* * * *}$ & 0.0806 \\
\hline$\$ 150,000$ or more & $0.8096^{* * *}$ & 0.0580 & $0.7736^{* * *}$ & 0.0513 & $0.6652^{* * *}$ & 0.0584 & $2.0664^{* * * *}$ & 0.0545 & $2.7260^{* * *}$ & 0.0935 \\
\hline $\begin{array}{l}\text { Had unexpected large } \\
\text { drop in income in past } \\
12 \text { months (ref: No) }\end{array}$ & $-0.2343^{* * *}$ & 0.0259 & -0.0346 & 0.0229 & $-0.1733^{* * *}$ & 0.0260 & $-0.2722^{* * *}$ & 0.0243 & $-0.4444^{* * *}$ & 0.0417 \\
\hline $\begin{array}{l}\text { Banking status } \\
\text { (ref: No) }\end{array}$ & $0.3468^{* * *}$ & 0.0428 & $0.5097^{* * *}$ & 0.0378 & $0.7883^{* * *}$ & 0.0430 & $1.2159^{* * *}$ & 0.0402 & $1.8317^{* * *}$ & 0.0689 \\
\hline Constant & $0.7621^{* * *}$ & 0.1175 & $3.3975^{* * *}$ & 0.1033 & $3.5744^{* * *}$ & 0.1166 & $0.5565^{* * *}$ & 0.1369 & $-6.4823^{* * *}$ & 0.1893 \\
\hline $\begin{array}{l}\text { State fixed effect } \\
\text { (State of residence) }\end{array}$ & Included & & Included & & Included & & Included & & Included & \\
\hline Adjusted R-squared & 0.2911 & & 0.1700 & & 0.1423 & & 0.4377 & & 0.4251 & \\
\hline F-value & 102.08 & $<.0001$ & 51.43 & $<.0001$ & 41.85 & $<.0001$ & 192.65 & $<.0001$ & 183.02 & $<.0001$ \\
\hline
\end{tabular}

Unweighted results. Significance level: ${ }^{*} p<.05,{ }^{* * *} p<.01,{ }^{* * * *} p<.001$. 
Racial/ethnic differences in financial capability

Table 3. Ordinary least squares regressions on financial capability, source of financial education, 2018 NFCS

\begin{tabular}{|c|c|c|c|c|c|c|c|c|c|c|}
\hline \multirow[t]{2}{*}{ Variables } & \multicolumn{2}{|c|}{$\begin{array}{c}\text { (1) Objective financial } \\
\text { knowledge }\end{array}$} & \multicolumn{2}{|c|}{$\begin{array}{c}\text { (2) Subjective } \\
\text { financial knowledge }\end{array}$} & \multicolumn{2}{|c|}{$\begin{array}{l}\text { (3) Perceived financial } \\
\text { capability }\end{array}$} & \multicolumn{2}{|c|}{$\begin{array}{c}\text { (4) Desirable financial } \\
\text { behaviors }\end{array}$} & \multicolumn{2}{|c|}{$\begin{array}{c}\text { (5) Financial } \\
\text { capability index }\end{array}$} \\
\hline & Coeff. & S.D. & Coeff. & S.D. & Coeff. & S.D. & Coeff. & S.D. & Coeff. & S.D. \\
\hline \multicolumn{11}{|l|}{ Race/ethnicity (ref: White) } \\
\hline Black & $-0.5337^{* * *}$ & 0.0357 & $0.1529^{* * *}$ & 0.0315 & 0.0417 & 0.0359 & $-0.1145^{* * *}$ & 0.0335 & $-0.2513^{* * *}$ & 0.0574 \\
\hline Hispanic & $-0.2197^{* * *}$ & 0.0366 & 0.0192 & 0.0323 & $-0.0804^{*}$ & 0.0368 & $-0.0864^{*}$ & 0.0344 & $-0.2246^{* * *}$ & 0.0589 \\
\hline \multicolumn{11}{|c|}{ Source of financial education (ref: No financial education) } \\
\hline High school only & $0.3524^{* * *}$ & 0.0438 & $0.1838^{* * *}$ & 0.0386 & $0.1581^{* * *}$ & 0.0440 & $0.1147^{* *}$ & 0.0411 & $0.5271^{* * *}$ & 0.0704 \\
\hline College only & $0.4718^{* * *}$ & 0.0476 & $0.3184^{* * *}$ & 0.0419 & $0.1590^{* * * *}$ & 0.0478 & $0.1570^{* * *}$ & 0.0446 & $0.7267^{* * *}$ & 0.0764 \\
\hline Employer only & $0.4355^{* * *}$ & 0.0627 & $0.3949^{* * *}$ & 0.0553 & $0.1314^{*}$ & 0.0631 & $0.2664^{* * *}$ & 0.0589 & $0.8070^{* * *}$ & 0.1008 \\
\hline High school and college only & $0.4846^{* * *}$ & 0.0582 & $0.4892^{* * *}$ & 0.0513 & $0.3283^{* * *}$ & 0.0585 & $0.3871^{* * *}$ & 0.0546 & $1.1103^{* * *}$ & 0.0936 \\
\hline High school and employer only & $0.3517^{* * *}$ & 0.0806 & $0.6097^{* * *}$ & 0.0710 & $0.3367^{* * *}$ & 0.0810 & $0.5870^{* * *}$ & 0.0756 & $1.2411^{* * *}$ & 0.1295 \\
\hline College and employer only & $0.4744^{* * *}$ & 0.0709 & $0.5055^{* * *}$ & 0.0625 & $0.2491^{* * *}$ & 0.0713 & $0.4001^{* * *}$ & 0.0665 & $1.0707^{* * *}$ & 0.1140 \\
\hline $\begin{array}{l}\text { High school, college and } \\
\text { employer }\end{array}$ & $0.2965^{* * *}$ & 0.0573 & $0.8905^{* * *}$ & 0.0505 & $0.5838^{* * *}$ & 0.0576 & $0.5667^{* * *}$ & 0.0538 & $1.5722^{* * *}$ & 0.0921 \\
\hline Constant & $0.7703^{* * *}$ & 0.1176 & $3.4329^{* * *}$ & 0.1030 & $3.6036^{* * *}$ & 0.1166 & $0.5883^{* * *}$ & 0.1367 & $-6.4087^{* * *}$ & 0.1891 \\
\hline Control variables & Included & & Included & & Included & & Included & & Included & \\
\hline $\begin{array}{l}\text { State fixed effect } \\
\text { (State of residence) }\end{array}$ & Included & & Included & & Included & & Included & & Included & \\
\hline Adjusted R-squared & 0.2917 & & 0.1773 & & 0.1446 & & 0.4404 & & 0.4289 & \\
\hline F-value & 95.24 & $<.0001$ & 49.98 & $<.0001$ & 39.68 & $<.0001$ & 181.06 & $<.0001$ & 172.83 & $<.0001$ \\
\hline
\end{tabular}

Unweighted results. Control variables are the same as Table 2 . Significance level: ${ }^{*} p<.05,{ }^{* *} p<.01,{ }^{* * *} p<.001$. 
Racial/ethnic differences in financial capability

Table 4. Ordinary least squares regressions on financial capability, sub-sample of receiving financial education, 2018 NFCS

\begin{tabular}{|c|c|c|c|c|c|c|c|c|c|c|}
\hline \multirow[t]{2}{*}{ Variables } & \multicolumn{2}{|c|}{$\begin{array}{l}\text { (1) Objective financial } \\
\text { knowledge }\end{array}$} & \multicolumn{2}{|c|}{$\begin{array}{l}\text { (2) Subjective financial } \\
\text { knowledge }\end{array}$} & \multicolumn{2}{|c|}{$\begin{array}{l}\text { (3) Perceived financial } \\
\text { capability }\end{array}$} & \multicolumn{2}{|c|}{$\begin{array}{c}\text { (4) Desirable financial } \\
\text { behaviors }\end{array}$} & \multicolumn{2}{|c|}{$\begin{array}{l}\text { (5) Financial capability } \\
\text { index }\end{array}$} \\
\hline & Coeff. & S.D. & Coeff. & S.D. & Coeff. & S.D. & Coeff. & S.D. & Coeff. & S.D. \\
\hline \multicolumn{11}{|c|}{ Race/ethnicity (ref: White) } \\
\hline Black & $-0.5847^{* * *}$ & 0.0672 & 0.0345 & 0.0492 & $0.1503^{*}$ & 0.0633 & 0.0520 & 0.0648 & -0.2018 & 0.0958 \\
\hline Hispanic & $-0.2812^{* * *}$ & 0.0710 & -0.0789 & 0.0520 & $-0.2775^{* * *}$ & 0.0669 & -0.0105 & 0.0685 & $-0.4242^{* * *}$ & 0.1013 \\
\hline \multicolumn{11}{|c|}{ Total hours of financial education received (ref: 1-2 hours) } \\
\hline 3-10 hours & $0.1529^{*}$ & 0.0606 & -0.0099 & 0.0444 & -0.0341 & 0.0571 & $0.1399^{*}$ & 0.0585 & 0.1449 & 0.0864 \\
\hline More than 10 hours & $0.4433^{* * *}$ & 0.0535 & 0.0064 & 0.0392 & 0.0222 & 0.0505 & $0.1568^{* *}$ & 0.0517 & $0.3829^{* * *}$ & 0.0763 \\
\hline $\begin{array}{l}\text { Quality of the } \\
\text { financial education }\end{array}$ & 0.0125 & 0.0152 & $0.3515^{* * *}$ & 0.0111 & $0.3496^{* * *}$ & 0.0143 & $0.1198^{* * *}$ & 0.0147 & $0.5021^{* * *}$ & 0.0217 \\
\hline Constant & 1.1364 & 0.2954 & $2.7059^{* * *}$ & 0.2202 & $3.4070^{* * *}$ & 0.2896 & 0.4264 & 0.3332 & $-6.7781^{* * *}$ & 0.4210 \\
\hline Control variables & Included & & Included & & Included & & Included & & Included & \\
\hline $\begin{array}{l}\text { State fixed effect } \\
\text { (State of residence) }\end{array}$ & Included & & Included & & Included & & Included & & Included & \\
\hline Adjusted R-squared & 0.3169 & & 0.3372 & & 0.1875 & & 0.4313 & & 0.5075 & \\
\hline F-value & 27.38 & $<.0001$ & 29.93 & $<.0001$ & 14.12 & $<.0001$ & 44.12 & $<.0001$ & 59.60 & $<.0001$ \\
\hline
\end{tabular}

Unweighted results. Control variables are the same as Table 2 . Significance level: ${ }^{*} p<.05,{ }^{* *} p<.01,{ }^{* * *} p<.001$. 
Racial/ethnic differences in financial capability

Table 5. Blinder-Oaxaca Decomposition Analysis, Black vs. White, 2018 NFCS

\begin{tabular}{|c|c|c|c|c|c|c|c|c|c|c|}
\hline \multirow[b]{2}{*}{ Component } & \multicolumn{2}{|c|}{$\begin{array}{l}\text { (1) Objective financial } \\
\text { knowledge }\end{array}$} & \multicolumn{2}{|c|}{$\begin{array}{l}\text { (2) Subjective financial } \\
\text { knowledge }\end{array}$} & \multicolumn{2}{|c|}{$\begin{array}{l}\text { (3) Perceived financial } \\
\text { capability }\end{array}$} & \multicolumn{2}{|c|}{$\begin{array}{c}\text { (4) Desirable financial } \\
\text { behaviors }\end{array}$} & \multicolumn{2}{|c|}{$\begin{array}{l}\text { (5) Financial capability } \\
\text { index }\end{array}$} \\
\hline & $\begin{array}{l}\text { Contributi } \\
\text { on to } \\
\text { difference } \\
\end{array}$ & $\begin{array}{c}\% \text { of } \\
\text { explained } \\
\text { difference } \\
\end{array}$ & $\begin{array}{l}\text { Contributi } \\
\text { on to } \\
\text { difference } \\
\end{array}$ & $\begin{array}{c}\% \text { of } \\
\text { explained } \\
\text { difference } \\
\end{array}$ & $\begin{array}{l}\text { Contributi } \\
\text { on to } \\
\text { difference } \\
\end{array}$ & $\begin{array}{c}\% \text { of } \\
\text { explained } \\
\text { difference } \\
\end{array}$ & $\begin{array}{l}\text { Contributi } \\
\text { on to } \\
\text { difference } \\
\end{array}$ & $\begin{array}{c}\% \text { of } \\
\text { explained } \\
\text { difference } \\
\end{array}$ & $\begin{array}{l}\text { Contributi } \\
\text { on to } \\
\text { difference } \\
\end{array}$ & $\begin{array}{c}\% \text { of } \\
\text { explained } \\
\text { difference }\end{array}$ \\
\hline $\begin{array}{l}\text { Financial } \\
\text { education }\end{array}$ & $0.0289^{* * *}$ & $-7.39 \%$ & $0.0285^{* * *}$ & $-11.88 \%$ & $0.0184^{* * *}$ & $-5.54 \%$ & $0.0189^{* * *}$ & $-2.98 \%$ & $0.0625^{* * *}$ & $-6.17 \%$ \\
\hline Age & $-0.1755^{* * *}$ & $44.77 \%$ & $-0.1163^{* * *}$ & $48.43 \%$ & $-0.1601^{* * *}$ & $48.23 \%$ & $-0.1597^{* * * *}$ & $25.16 \%$ & $-0.3953^{* * *}$ & $39.03 \%$ \\
\hline Gender & 0.0047 & $-1.20 \%$ & 0.0027 & $-1.14 \%$ & 0.0003 & $-0.08 \%$ & 0.0020 & $-0.31 \%$ & 0.0063 & $-0.62 \%$ \\
\hline Marital status & -0.0065 & $1.66 \%$ & -0.0041 & $1.70 \%$ & -0.0006 & $0.17 \%$ & $-0.0196^{* * *}$ & $3.09 \%$ & $-0.0188^{* *}$ & $1.86 \%$ \\
\hline Education & $-0.0409^{* * *}$ & $10.45 \%$ & $-0.0044^{* *}$ & $1.83 \%$ & $-0.0057^{* *}$ & $1.72 \%$ & $-0.0184^{* * *}$ & $2.90 \%$ & $-0.0430^{* * *}$ & $4.24 \%$ \\
\hline $\begin{array}{l}\text { Having a } \\
\text { dependent child }\end{array}$ & $-0.0195^{\text {**** }}$ & $4.98 \%$ & $0.0060^{*}$ & $-2.49 \%$ & $-0.0086^{*}$ & $2.60 \%$ & $-0.0401^{* * *}$ & $6.32 \%$ & $-0.0366^{* * *}$ & $3.61 \%$ \\
\hline $\begin{array}{l}\text { Employment } \\
\text { status }\end{array}$ & -0.0025 & $0.65 \%$ & -0.0046 & $1.92 \%$ & -0.0008 & $0.24 \%$ & -0.0051 & $0.80 \%$ & -0.0085 & $0.84 \%$ \\
\hline Income & $-0.1069^{* * * *}$ & $27.28 \%$ & $-0.1045^{* * *}$ & $43.55 \%$ & $-0.0847^{* * *}$ & $25.51 \%$ & $-0.2728^{* * *}$ & $42.98 \%$ & $-0.3596^{* * *}$ & $35.51 \%$ \\
\hline Income drop & $-0.0459^{* * * *}$ & $11.72 \%$ & -0.0050 & $2.09 \%$ & $-0.0317^{* * *}$ & $9.55 \%$ & $-0.0511^{* * *}$ & $8.05 \%$ & $-0.0830^{* * *}$ & $8.19 \%$ \\
\hline Banking status & $-0.0277^{* * * *}$ & $7.07 \%$ & $-0.0383^{* * *}$ & $15.97 \%$ & $-0.0584^{* * *}$ & $17.60 \%$ & $-0.0889^{* * * *}$ & $14.00 \%$ & $-0.1367^{* * *}$ & $13.50 \%$ \\
\hline Total difference & $-0.9674^{* * *}$ & & -0.0245 & & $-0.2682^{* * *}$ & & $-0.7123^{* * *}$ & & $-1.2062^{* * *}$ & \\
\hline $\begin{array}{l}\text { Explained } \\
\text { difference }\end{array}$ & -0.3919 & & -0.2400 & & -0.3319 & & -0.6348 & & -1.0127 & \\
\hline $\begin{array}{l}\text { Unexplained } \\
\text { difference }\end{array}$ & -0.5754 & & 0.2156 & & 0.0636 & & -0.0774 & & -0.1935 & \\
\hline $\begin{array}{l}\% \text { of explained } \\
\text { difference to total } \\
\text { difference }\end{array}$ & & $40.5 \%$ & & $981.1 \%$ & & $123.7 \%$ & & $89.1 \%$ & & $84.0 \%$ \\
\hline
\end{tabular}


Racial/ethnic differences in financial capability

Table 6. Blinder-Oaxaca Decomposition Analysis, Hispanic vs. White, 2018 NFCS

\begin{tabular}{|c|c|c|c|c|c|c|c|c|c|c|}
\hline \multirow[b]{2}{*}{ Component } & \multicolumn{2}{|c|}{$\begin{array}{l}\text { (1) Objective financial } \\
\text { knowledge }\end{array}$} & \multicolumn{2}{|c|}{$\begin{array}{l}\text { (2) Subjective financial } \\
\text { knowledge }\end{array}$} & \multicolumn{2}{|c|}{$\begin{array}{l}\text { (3) Perceived financial } \\
\text { capability }\end{array}$} & \multicolumn{2}{|c|}{$\begin{array}{l}\text { (4) Desirable financial } \\
\text { behaviors }\end{array}$} & \multicolumn{2}{|c|}{$\begin{array}{l}\text { (5) Financial capability } \\
\text { index }\end{array}$} \\
\hline & $\begin{array}{l}\text { Contributi } \\
\text { on to } \\
\text { difference } \\
\end{array}$ & $\begin{array}{c}\% \text { of } \\
\text { explained } \\
\text { difference } \\
\end{array}$ & $\begin{array}{l}\text { Contributi } \\
\text { on to } \\
\text { difference } \\
\end{array}$ & $\begin{array}{c}\% \text { of } \\
\text { explained } \\
\text { difference }\end{array}$ & $\begin{array}{l}\text { Contributi } \\
\text { on to } \\
\text { difference } \\
\end{array}$ & $\begin{array}{c}\% \text { of } \\
\text { explained } \\
\text { difference } \\
\end{array}$ & $\begin{array}{l}\text { Contributi } \\
\text { on to } \\
\text { difference } \\
\end{array}$ & $\begin{array}{c}\% \text { of } \\
\text { explained } \\
\text { difference } \\
\end{array}$ & $\begin{array}{l}\text { Contributi } \\
\text { on to } \\
\text { difference } \\
\end{array}$ & $\begin{array}{c}\% \text { of } \\
\text { explained } \\
\text { difference } \\
\end{array}$ \\
\hline $\begin{array}{l}\text { Financial } \\
\text { education }\end{array}$ & 0.0076 & $-1.91 \%$ & 0.0070 & $-2.78 \%$ & 0.0035 & $-1.09 \%$ & 0.0044 & $-0.82 \%$ & 0.0148 & $-1.54 \%$ \\
\hline Age & $-0.2144^{* * * *}$ & $53.82 \%$ & $-0.1540^{* * *}$ & $61.21 \%$ & $-0.2052^{* * *}$ & $63.83 \%$ & $-0.1996^{* * *}$ & $37.22 \%$ & $-0.5010^{* * *}$ & $52.13 \%$ \\
\hline Gender & $-0.0326^{* * *}$ & $8.18 \%$ & $-0.0164^{* * *}$ & $6.52 \%$ & -0.0016 & $0.49 \%$ & $-0.0126^{* * *}$ & $2.36 \%$ & $-0.0407^{* * *}$ & $4.24 \%$ \\
\hline Marital status & -0.0011 & $0.27 \%$ & -0.0022 & $0.87 \%$ & -0.0007 & $0.21 \%$ & $-0.0058^{* * *}$ & $1.08 \%$ & $-0.0061^{* *}$ & $0.64 \%$ \\
\hline Education & $-0.0157^{*}$ & $3.94 \%$ & -0.0021 & $0.84 \%$ & $-0.0028^{*}$ & $0.88 \%$ & $-0.0076^{*}$ & $1.41 \%$ & $-0.0175^{*}$ & $1.82 \%$ \\
\hline $\begin{array}{l}\text { Having a } \\
\text { dependent child }\end{array}$ & $-0.0234^{* * *}$ & $5.87 \%$ & $0.0099^{* *}$ & $-3.93 \%$ & $-0.0107^{* *}$ & $3.34 \%$ & $-0.0521^{* * *}$ & $9.72 \%$ & $-0.0444^{* * *}$ & $4.62 \%$ \\
\hline $\begin{array}{l}\text { Employment } \\
\text { status }\end{array}$ & -0.0055 & $1.39 \%$ & -0.0051 & $2.04 \%$ & -0.0014 & $0.43 \%$ & $-0.0084^{*}$ & $1.57 \%$ & $-0.0131^{*}$ & $1.36 \%$ \\
\hline Income & $-0.0739^{* * *}$ & $18.56 \%$ & $-0.0609^{* * *}$ & $24.21 \%$ & $-0.0504^{* * *}$ & $15.67 \%$ & $-0.1740^{* * *}$ & $32.44 \%$ & $-0.2261^{* * *}$ & $23.53 \%$ \\
\hline Income drop & $-0.0236^{* * * *}$ & $5.92 \%$ & $-0.0070^{*}$ & $2.79 \%$ & $-0.0201^{* * *}$ & $6.26 \%$ & $-0.0311^{* * * *}$ & $5.80 \%$ & $-0.0513^{* * *}$ & $5.34 \%$ \\
\hline Banking status & $-0.0157^{* * *}$ & $3.95 \%$ & $-0.0207^{* * *}$ & $8.22 \%$ & $-0.0321^{* * *}$ & $9.98 \%$ & $-0.0494^{* * *}$ & $9.22 \%$ & $-0.0755^{* * *}$ & $7.85 \%$ \\
\hline Total difference & $-0.6352^{* * * *}$ & & $-0.2247^{* * *}$ & & $-0.3766^{* * *}$ & & $-0.5855^{* * *}$ & & $-1.1518^{* * *}$ & \\
\hline $\begin{array}{l}\text { Explained } \\
\text { difference }\end{array}$ & -0.3983 & & -0.2515 & & -0.3216 & & -0.5363 & & -0.9611 & \\
\hline $\begin{array}{l}\text { Unexplained } \\
\text { difference }\end{array}$ & -0.2368 & & 0.0268 & & -0.0551 & & -0.0492 & & -0.1908 & \\
\hline $\begin{array}{l}\% \text { of explained } \\
\text { difference to total } \\
\text { difference }\end{array}$ & & $62.7 \%$ & 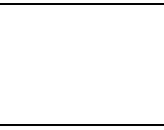 & $111.9 \%$ & & $85.4 \%$ & & $91.6 \%$ & & $83.4 \%$ \\
\hline
\end{tabular}


Racial/ethnic differences in financial capability

Table 7. Blinder-Oaxaca Decomposition Analysis, Black vs. Hispanic, 2018 NFCS

\begin{tabular}{|c|c|c|c|c|c|c|c|c|c|c|}
\hline \multirow[b]{2}{*}{ Component } & \multicolumn{2}{|c|}{$\begin{array}{l}\text { (1) Objective financial } \\
\text { knowledge }\end{array}$} & \multicolumn{2}{|c|}{$\begin{array}{l}\text { (2) Subjective financial } \\
\text { knowledge }\end{array}$} & \multicolumn{2}{|c|}{$\begin{array}{l}\text { (3) Perceived financial } \\
\text { capability }\end{array}$} & \multicolumn{2}{|c|}{$\begin{array}{l}\text { (4) Desirable financial } \\
\text { behaviors }\end{array}$} & \multicolumn{2}{|c|}{$\begin{array}{l}\text { (5) Financial capability } \\
\text { index }\end{array}$} \\
\hline & $\begin{array}{l}\text { Contributi } \\
\text { on to } \\
\text { difference } \\
\end{array}$ & $\begin{array}{c}\% \text { of } \\
\text { explained } \\
\text { difference } \\
\end{array}$ & $\begin{array}{l}\text { Contributi } \\
\text { on to } \\
\text { difference } \\
\end{array}$ & $\begin{array}{c}\% \text { of } \\
\text { explained } \\
\text { difference }\end{array}$ & $\begin{array}{l}\text { Contributi } \\
\text { on to } \\
\text { difference } \\
\end{array}$ & $\begin{array}{c}\% \text { of } \\
\text { explained } \\
\text { difference } \\
\end{array}$ & $\begin{array}{l}\text { Contributi } \\
\text { on to } \\
\text { difference } \\
\end{array}$ & $\begin{array}{c}\% \text { of } \\
\text { explained } \\
\text { difference } \\
\end{array}$ & $\begin{array}{l}\text { Contributi } \\
\text { on to } \\
\text { difference } \\
\end{array}$ & $\begin{array}{c}\% \text { of } \\
\text { explained } \\
\text { difference }\end{array}$ \\
\hline $\begin{array}{l}\text { Financial } \\
\text { education }\end{array}$ & $0.0160^{* *}$ & $481.9 \%$ & $0.0228^{* * *}$ & $-302.8 \%$ & $0.0160^{* *}$ & $-60.4 \%$ & $0.0211^{* * *}$ & $-19.2 \%$ & $0.0499^{* * *}$ & $-58.5 \%$ \\
\hline Age & $0.0353^{* * *}$ & $1,064.9 \%$ & $0.0226^{* * *}$ & $-300.2 \%$ & $0.0283^{* * *}$ & $-107.0 \%$ & $0.0153^{* *}$ & $-13.9 \%$ & $0.0665^{* * *}$ & $-78.0 \%$ \\
\hline Gender & $0.0201^{* * *}$ & $605.7 \%$ & $0.0265^{* * *}$ & $-352.1 \%$ & 0.0014 & $-5.2 \%$ & $0.0200^{* * *}$ & $-18.2 \%$ & $0.0447^{* * *}$ & $-52.5 \%$ \\
\hline Marital status & 0.0054 & $161.8 \%$ & $-0.0167^{* *}$ & $222.4 \%$ & -0.0048 & $18.3 \%$ & $-0.0156^{*}$ & $14.2 \%$ & $-0.0216^{*}$ & $25.3 \%$ \\
\hline Education & $-0.0232^{* *}$ & $-699.1 \%$ & -0.0024 & $31.5 \%$ & $-0.0078^{*}$ & $29.5 \%$ & $-0.0134^{*}$ & $12.2 \%$ & $-0.0290^{*}$ & $34.0 \%$ \\
\hline $\begin{array}{l}\text { Having a } \\
\text { dependent child }\end{array}$ & 0.0008 & $24.1 \%$ & -0.0019 & $24.9 \%$ & 0.0016 & $-6.0 \%$ & 0.0005 & $-0.4 \%$ & 0.0004 & $-0.5 \%$ \\
\hline $\begin{array}{l}\text { Employment } \\
\text { status }\end{array}$ & -0.0037 & $-111.9 \%$ & -0.0037 & $49.8 \%$ & -0.0015 & $5.6 \%$ & -0.0059 & $5.3 \%$ & -0.0095 & $11.1 \%$ \\
\hline Income & $-0.0264^{* * *}$ & $-796.2 \%$ & $-0.0331^{* * * *}$ & $440.2 \%$ & $-0.0285^{* * *}$ & $107.7 \%$ & $-0.0788^{* * *}$ & $71.7 \%$ & $-0.1060^{* * *}$ & $124.3 \%$ \\
\hline Income drop & $-0.0117^{* *}$ & $-353.1 \%$ & -0.0008 & $11.3 \%$ & -0.0067 & $25.2 \%$ & $-0.0164^{* * * *}$ & $14.9 \%$ & $-0.0218^{* *}$ & $25.6 \%$ \\
\hline Banking status & $-0.0092^{*}$ & $-278.0 \%$ & $-0.0207^{* *}$ & $275.0 \%$ & $-0.0244^{* *}$ & $92.4 \%$ & $-0.0367^{* *}$ & $33.4 \%$ & $-0.0589^{* *}$ & $69.1 \%$ \\
\hline Total difference & $-0.3322^{* * * *}$ & & $0.2003^{* * *}$ & & $0.1084^{* * *}$ & & $-0.1268^{* * *}$ & & -0.0544 & \\
\hline $\begin{array}{l}\text { Explained } \\
\text { difference }\end{array}$ & 0.0033 & & -0.0075 & & -0.0265 & & -0.1099 & & -0.0853 & \\
\hline $\begin{array}{l}\text { Unexplained } \\
\text { difference }\end{array}$ & -0.3355 & & 0.2078 & & 0.1349 & & -0.0492 & & 0.0308 & \\
\hline $\begin{array}{l}\% \text { of explained } \\
\text { difference to total } \\
\text { difference }\end{array}$ & & $-1.0 \%$ & 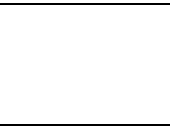 & $-3.8 \%$ & & $-24.4 \%$ & & $86.7 \%$ & & $156.7 \%$ \\
\hline
\end{tabular}


Racial/ethnic differences in financial capability

Appendix 1. Descriptive statistics of sample characteristics, 2018 NFCS

\begin{tabular}{|c|c|c|c|c|}
\hline Variables & Pooled sample & White & Black & Hispanic \\
\hline \multicolumn{5}{|l|}{ Race/ethnicity } \\
\hline White & $80.4 \%$ & $100 \%$ & - & - \\
\hline Black & $10.2 \%$ & - & $100 \%$ & - \\
\hline Hispanic & $9.3 \%$ & - & - & $100 \%$ \\
\hline Received financial education & $23.7 \%$ & $22.9 \%$ & $29.4 \%^{* * *}$ & $24.6 \%$ \\
\hline \multicolumn{5}{|c|}{ Total hours of financial education received } \\
\hline $1-2$ hours & $19.6 \%$ & $18.2 \%$ & $26.6 \%{ }^{* * *}$ & $22.2 \%{ }^{*}$ \\
\hline 3-10 hours & $23.9 \%$ & $22.3 \%$ & $32.1 \%{ }^{* * *}$ & $25.8 \%$ \\
\hline More than 10 hours & $56.5 \%$ & $59.5 \%$ & $41.3 \%^{* * *}$ & $52.0 \% * *$ \\
\hline $\begin{array}{l}\text { Quality of the financial education } \\
(1-7), \text { mean (median) }\end{array}$ & $5.4(5.0)$ & $5.3(5.0)$ & $5.8(6.0)^{* * *}$ & $5.3(5.0)$ \\
\hline Age of respondent, mean (median) & $48.1(49.0)$ & $50.0(52.0)$ & $41.3(38.0)^{* * *}$ & $39.2(37.0)^{* * *}$ \\
\hline \multicolumn{5}{|l|}{ Gender } \\
\hline Male & $45.0 \%$ & $45.5 \%$ & 46.4 & $39.7 \%$ *** \\
\hline Female & $55.0 \%$ & $54.5 \%$ & 53.6 & $60.3 \%^{* * *}$ \\
\hline \multicolumn{5}{|l|}{ Marital status } \\
\hline Married & $54.4 \%$ & $58.1 \%$ & $31.4 \%^{* * *}$ & $46.9 \%$ *** \\
\hline Single & $28.5 \%$ & $24.1 \%$ & $53.4 \%{ }^{* * *}$ & $39.2 \%{ }^{* * *}$ \\
\hline Separated/divorce/widow & $17.1 \%$ & $17.8 \%$ & $15.2 \%{ }^{* * *}$ & $13.9 \%{ }^{* * *}$ \\
\hline \multicolumn{5}{|l|}{ Education } \\
\hline Less than high school & $2.2 \%$ & $2.1 \%$ & $2.3 \%$ & $2.8 \%$ \\
\hline High school diploma & $25.7 \%$ & $25.8 \%$ & $25.9 \%$ & $24.7 \%$ \\
\hline Some college & $27.1 \%$ & $25.7 \%$ & $35.8 \% \%^{* * *}$ & $30.4 \%{ }^{* * *}$ \\
\hline Associate degree & $10.6 \%$ & $10.4 \%$ & $10.8 \%$ & $12.3 \%{ }^{*}$ \\
\hline Bachelor degree & $21.4 \%$ & $22.1 \%$ & $17.1 \%{ }^{* * *}$ & $19.7 \%^{*}$ \\
\hline Post-bachelor degree & $13.0 \%$ & $13.9 \%$ & $8.1 \%{ }^{* * *}$ & $10.1 \%{ }^{* * *}$ \\
\hline Presence of dependent child & $35.8 \%$ & $32.9 \%$ & $46.6 \%$ *** & $48.8 \%$ *** \\
\hline \multicolumn{5}{|l|}{ Employment status } \\
\hline Full-time worker & $40.9 \%$ & $39.6 \%$ & $45.9 \%^{* * *}$ & $46.7 \%^{* * *}$ \\
\hline
\end{tabular}


Racial/ethnic differences in financial capability

\begin{tabular}{|c|c|c|c|c|}
\hline Variables & Pooled sample & White & Black & Hispanic \\
\hline Self-employed & $7.3 \%$ & $7.2 \%$ & $8.5 \%^{*}$ & $7.0 \%$ \\
\hline Part-time worker & $8.6 \%$ & $8.2 \%$ & $10.2 \%^{* * *}$ & $10.9 \%^{* * *}$ \\
\hline Homemaker & $7.5 \%$ & $7.5 \%$ & $5.0 \%^{* * *}$ & $9.6 \% \%^{* * *}$ \\
\hline Student & $3.0 \%$ & $2.4 \%$ & $5.5 \% \%^{* * *}$ & $5.9 \%^{* * * *}$ \\
\hline Disabled & $5.2 \%$ & $5.3 \%$ & $5.2 \%$ & $4.6 \%$ \\
\hline Unemployed & $4.2 \%$ & $3.5 \%$ & $7.9 \%^{* * *}$ & $6.6 \% \%^{* * * *}$ \\
\hline Retired & $23.3 \%$ & $26.4 \%$ & $11.9 \%^{* * *}$ & $8.7 \%^{* * * *}$ \\
\hline \multicolumn{5}{|l|}{ Household income } \\
\hline Less than $\$ 15,000$ & $10.1 \%$ & $8.8 \%$ & $17.6 \%^{* * *}$ & $13.2 \%{ }^{* * * *}$ \\
\hline$\$ 15,000-\$ 24,999$ & $10.1 \%$ & $9.7 \%$ & $13.4 \%^{* * *}$ & $10.6 \%$ \\
\hline$\$ 25,000-\$ 34,999$ & $10.8 \%$ & $10.2 \%$ & $12.3 \%^{* * *}$ & $13.6 \%^{* * *}$ \\
\hline$\$ 35,000-\$ 49,999$ & $14.9 \%$ & $14.7 \%$ & $14.3 \%$ & $17.3 \%^{* * * *}$ \\
\hline$\$ 50,000-\$ 74,999$ & $19.5 \%$ & $19.9 \%$ & $17.2 \%^{* * *}$ & $18.6 \%$ \\
\hline$\$ 75,000-\$ 99,999$ & $14.6 \%$ & $14.8 \%$ & $15.0 \%$ & $12.1 \%^{* * * *}$ \\
\hline$\$ 100,000-\$ 149,999$ & $13.0 \%$ & $14.2 \%$ & $7.0 \%{ }^{* * * *}$ & $9.6 \%{ }^{* * * *}$ \\
\hline$\$ 150,000$ or more & $7.0 \%$ & $7.7 \%$ & $3.2 \%{ }^{* * *}$ & $5.0 \%{ }^{* * * *}$ \\
\hline $\begin{array}{l}\text { Had unexpected large drop in } \\
\text { income in past } 12 \text { months }\end{array}$ & $20.4 \%$ & $17.9 \%$ & $34.6 \%{ }^{* * *}$ & $27.2 \%^{* * *}$ \\
\hline Having banking account & $93.5 \%$ & $94.6 \%$ & $87.6 \%{ }^{* * *}$ & $90.8 \% \%^{\text {**** }}$ \\
\hline
\end{tabular}

Unweighted results. Total hours of financial education received and quality of financial education are from the subsample of receiving financial education. T-test and Chi-square test were conducted for two pair-wise comparisons in each variable (i.e., Black-White, Hispanic-White). Significance level: ${ }^{*} p<.1,{ }^{* *} p<.05,{ }^{* * * *} p$ $<.01$. 